
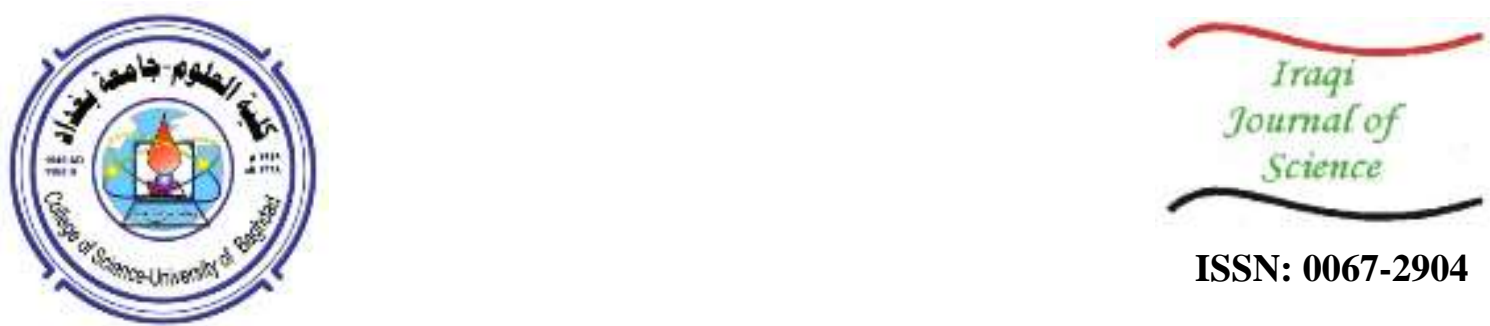

ISSN: 0067-2904

\title{
Monitoring of the Immune Response Activity in Iraqi Patients Infected with Cutaneous Leishmaniasis by IFN- $\gamma$ and MIG Evaluation During Different Stages of Infection
}

\author{
Reem Aladdin Jameel*, B. N. Al-Qadhi \\ Department of Biology, College of Science, University of Baghdad, Baghdad, Iraq
}

Received: 2/9/ $2019 \quad$ Accepted: 31/10/2019

\begin{abstract}
Cutaneous leishmaniasis (CL) is one of the most prevalent cutaneous parasitic protozoan infections in Iraq; characterized by a chronic infection and granulomatous disease that invades the skin. Type 1 immune was predominates in CL patients with exacerbated production of pro-inflammatory cytokine, therefore this study aimed to evaluate serum level of interferon gamma (IFN- $\gamma$ ) and monokine induce by interferon gamma (MIG/CXCl9) as a useful markers of disease development in patients during different stage of infection $(<1$ month .. early , 1-6 month.. chronic and $>6$ months.. late). The result showed that there was an early effort to eliminate the parasite proliferation which illustrated by a high significant increase of both IFN- $\gamma$ and MIG during the early stage of infection, but this response was downregulated during the chronic stage of infection, which observed by low levels of both studied cytokine and monokine, nevertheless this down-regulation was transient where the levels to increase returns during the late stage of infection. The evaluation of IFN- $\gamma$ and MIG considered as a biological markers of disease activity in each stage of infection.
\end{abstract}

Keywords: Cutaneous leishmaniasis, IFN- $\gamma$, MIG, stage of infection.

\section{متابعه فعاليه الاستجابه المناعيه في المرضى العراقيين المصابين باللثمانيا الجلديه بواسطه تقييم خلال مراحل المرض المختلفة MIG و IFN-}

\author{
ريم علاء الدين* ، بان نوري القاضي \\ جامعة بغداد، كلية العلوم، قسم علوم الحياة،بغداد، العراق لاقيان
}

الخلاصة

مرض اللثمانيا الجلدية هو احد اكثر الاصابات الجلدية الطفيلية الابتدائية في العراق. يتمثل بالاصابة

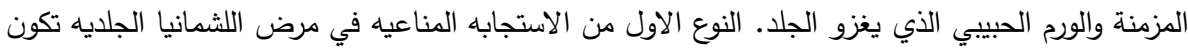

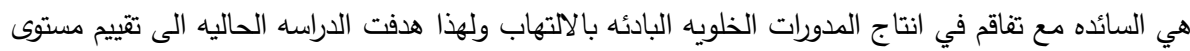

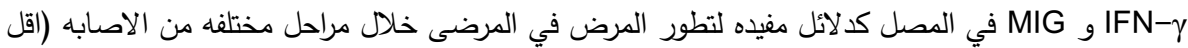

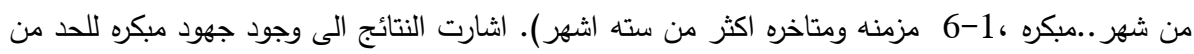

تكاثر الطفيليات والتي تمثلت بارتفاع معنوي في كلا IFN- و و MIG خلال المرحله المبكره من الاصابه، لكن

هذه الاستجابة تناقصت خلال مرحله المرض المزمنه والتي توضحت بنقصان مستوى كلا العاملين

الددروسين، ومع ذلك هذا التناقص كان عابر وذلك لعوده ازدياد كلا العاملين الددرسين الى الارتفاع خلال

*Email:a.d.mema@yahoo.com 


$$
\text { كل مرحله من مر احل الاصنابة. }
$$

\section{Introduction}

Leishmaniasis is a severe parasitic disease, viewed via the World Health Organization (WHO) to be one of the most necessary ignored diseases globally. Approximately 12 million people are infected with greater than twenty distinct pathogenic Leishmania species worldwide (i.e. tropical and subtropical areas of Asia, the Middle East, sub-Saharan Africa, and South America) [1].

The disease is caused by protozoa belonging to the genus Leishmania and transmitted through the chunk of a $2-3 \mathrm{~mm}$ lengthy insect vector, the Phlebotomus and Lutzomyia sand fly [2]. The medical photo of leishmaniasis is heterogeneous with a large spectrum of human diseases [3]. Leishmania parasite can give rise to different form depending on the infecting species such localized cutaneous leishmaniasis (CL), CL with mucosal involvement (MCL), visceral leishmaniasis (VL) [4].

According to [5] CL is the most common form of the disease, with many different Leishmania species responsible for signs and symptoms from both the Old World (L. major, L. tropica, $L$. aethiopica) and New World (L. mexicana, L. amazonesis, L. braziliensis, L. panamensis, $L$. guanensis).

The immune response to $\mathrm{CL}$ is characterized by a mixed T-helper 1 and T-helper 2 immune response [6]. The Th1 immune response is necessary to manage parasite growth and to stop Leishmania proliferation and dissemination, [7]. Interleukin-2 (IL-2) and interferon-gamma (IFN-gamma) are usually produce in large amount by Th1 [8]. On the other hand, the Th2 immune response is responsible for development and chronicity of lesions in leishmania infection. Th2 cell characterized by production of IL4 and IL10 cytokine [9] .

Interferon gamma (IFN-Y) is a major Th1 derived cytokine that plays crucial role in controlling Leishmania infection [6]. It involves in induction of cidal activity against Leishmania parasite and induces the production of oxygen species [10].

One of the important immunological mediators in prime inflammation is monokine induced by IFN-Y (MIG/CXCL9) which is the predominant function of it is the recruitment of primed Tlymphocyte to sites of inflammation [11]. This monokine is a member of the CXC subfamily of chemokine. The manufacturing of MIG is specifically activated via IFN-Y and can also play necessary roles in improving the recruitment and activation of Th1 cells [12], and stimulate T-lymphocyte proliferation and enhance T-lymphocyte effector cytokine production [11].

\section{Materials and methods}

\section{Subject selection}

This study included two groups of individual:

- $\quad$ First group included sixty-six patients infected with cutaneous leshmaniasis collected from AL-Karama Hospital in Baghdad (42 male and 26 female), their ages ranged from 1 year to 55 years during the period November 2018 to February 2019.

- $\quad$ The second group includes forty healthy individuals, as a control group (22 male and 18 female), their ages ranged from 5 to 68 years.

All study participants signed the informed consent form agreeing to participate in the study. Questionnaire sheet was taken for each individual includes: Name, sex, age, duration of infection, the number of lesions, and treatment.

\section{Blood sample collection}

Five $\mathrm{ml}$ of venous blood was collected from each patient with a disposable syringe. The collected samples were placed in a vacuum tubes and left to stand at room temperature to clot formation after that the tubes were centrifuged at $3000 \mathrm{rmp}$, then the sera were collected in Eppendorf tubes and stored at $-20^{\circ} \mathrm{C}$ until used.

\section{Immunological assays}

Determination of IFN- $\gamma$

Measurements of IFN- $\gamma$ were performed according to the direction of the manufacturer of Abcam ELISA (ab100537) kit.

\section{Determination of MIG}

Measurements of MIG were performed according to the direction of the manufacturer of MyBio Source ELISA kit. 


\section{Statistical analysis}

The Statistical Analysis System- SAS [13] program was used to detect the effect of difference factors in study parameters. Least significant difference -LSD test (Analysis of Variation-ANOVA) and T-test was used to significant compare between means.

\section{Results and discussion \\ Cutaneous leishmaniasis \\ Sex distribution}

In this study the total numbers of cutaneous leishmaniasis patients were 66 individuals, 40/66 (60.6 $\%)$ males and 26/66 (39.39\%) females.

\section{Age distribution}

The ages of patients studied were ranged between 1 years to 55 years, the majority of patients were at the age of $<15$ years $28(42.42 \%)$.

\section{Body site of infection}

Different body parts of patients were found to be infected with CL which includes face, arms and legs, but the highest percentage was observed in arm 29/66 (43.93\%) following by legs 23/66 $(34.84 \%)$ and face $14 / 66(21.21 \%)$, Table-1.

\section{Duration of infection}

Duration of infection with CL in patients was ranged from $<1$ months to $>6$ months, Table-1.

\section{Number of lesions}

The number of lesions ranged between 1-18 in different body part,25/66 (37.87\%) of CL patients had one ulcerated lesion, 41/66 (62.12\%) with multiple ulcerated lesions, Table-1, Figure-1.

Table 1- The percentage of CL distribution according site of infection, duration of infection and number of lesions.

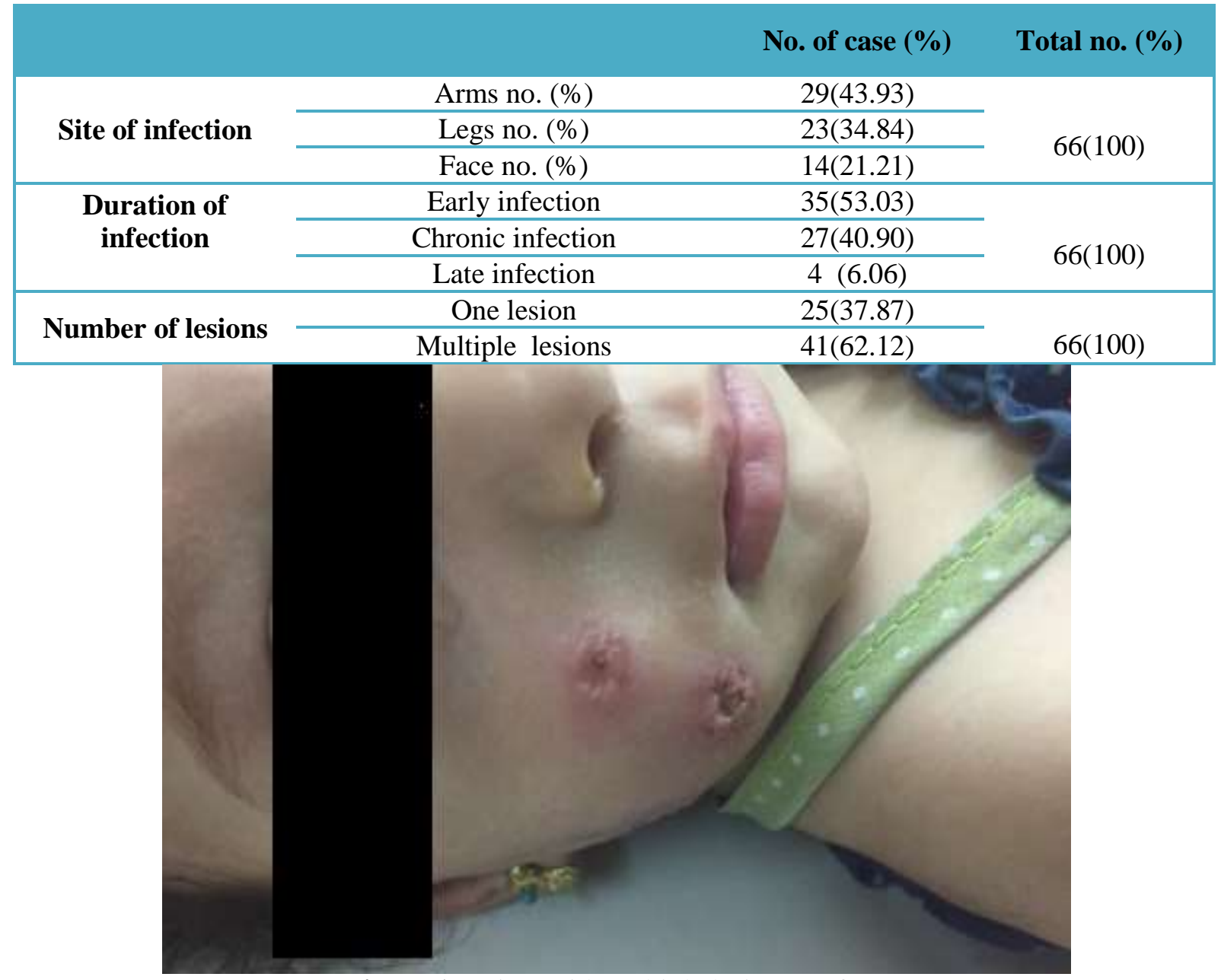

Figure 1-Patient with multiple lesions on face 


\section{Serological findings by ELISA \\ Gamma-interferon (IFN- $\gamma$ )}

The results of this study obtained that patients with CL had significant increased $(p<0.01)$ of IFN- $\gamma$ mean level ( $40.94 \pm 1.17 \mathrm{pg} / \mathrm{ml})$ in comparison to control group $(3.04 \pm 0.53 \mathrm{pg} / \mathrm{ml})$, Table- 2 .

Table 2-Mean level of IFN- $\gamma$ in CL patients in comparison to control group

\begin{tabular}{|cccc|}
\hline Group & Mean \pm SE $(\mathbf{p g} / \mathbf{m l})$ & T-test & P-value \\
\hline Patients & $40.94 \pm 1.17$ & $3.377 * *$ & 0.0001 \\
\hline Control & $3.04 \pm 0.53$ & $* *(\mathbf{P}<\mathbf{0 . 0 1})$. \\
\hline
\end{tabular}

This result was agreed with previous results by [14] who showed significant increase of IFN- $\gamma$ level in CL patients in comparison to control group while this result was disagreed with Al-Aubaidi [15] that obtained decreased level of IFN- $\gamma$ in CL patients in comparison to control group. These differences may relate to different kits or different type of sample or the strain of the parasite; but in fact the current result was tending to be more truth, especially when there is an early infection there is an acute inflammation so there is a high inflammatory cytokine level in comparison to control group. At the site of parasite entrance the cutaneous leishmanial lesions take place and begin as a small papule that develops into a nodule that ulcerates in the center [16].

This increase in IFN- $\gamma$ level in the current study is required to eliminate the intacellular parasite. Cell mediated immune responses plays an important role in control intra cellular infection and resolve disease of leishmaniasis [8]. Furthermore, resistance to infection or recovery is related with a Th-1 response that is based upon expression of IL-12, IFN- $\gamma$, and TNF- $\alpha$ with the production of nitric oxide (NO) [17]. Interferon gamma is a Th1 cytokine that plays an important role in limiting the growth of leishmania parasite and controlling the progression of disease by enhancing macrophages activity [18].

The current results also showed that patients with early CL $(<1$ months) had the highest significant increased $(\mathrm{p}<0.05)$ mean level $(44.05 \pm 2.19 \mathrm{pg} / \mathrm{ml})$ of IFN- $\gamma$ than other patients with different duration of infection. However, late CL (> 6 months) $(40.40 \pm 2.68 \mathrm{pg} / \mathrm{ml})$ mean level showed higher significant $(\mathrm{P}<0.05)$ in comparison to chronic stage $(1-6$ months $)(37.81 \pm 1.12 \mathrm{pg} / \mathrm{ml})$, Table- 3 .

Table 3- Mean concentration of IFN- $\gamma$ in CL patients according to duration of infection, number of lesion and treatment.

\begin{tabular}{|c|c|c|c|}
\hline \multicolumn{2}{|c|}{ Group } & Mean $\pm \mathrm{SE}(\mathrm{pg} / \mathrm{ml})$ & LSD value \\
\hline \multirow{3}{*}{$\begin{array}{c}\text { Duration of } \\
\text { infection }\end{array}$} & Early infection & $44.05 \pm 2.19$ & \multirow[b]{3}{*}{$6.016 *$} \\
\hline & Chronic infection & $37.81 \pm 1.12$ & \\
\hline & Late infection & $40.40 \pm 2.68$ & \\
\hline \multirow{2}{*}{$\begin{array}{l}\text { Number of } \\
\text { lesions }\end{array}$} & One lesion & $45.25 \pm 2.37$ & \multirow[b]{2}{*}{$4.631 * *$} \\
\hline & Multiple lesions & $38.79 \pm 1.10$ & \\
\hline \multirow{2}{*}{ Treatment } & With treatment & $44.60 \pm 1.69$ & \multirow[b]{2}{*}{$4.084 * *$} \\
\hline & Without treatment & $36.69 \pm 0.85$ & \\
\hline & $*(\mathbf{P}<0.05), * *(\mathbf{P}<$ & Non-Significant. & \\
\hline
\end{tabular}

This results was in agreement with Bacellar et al. [19] who showed that IFN- $\gamma$ and TNF- $\alpha$ were present at higher concentrations during the primary Leishmania infections when compared to controls. These cytokines activate macrophage that plays a crucial role in parasite killing.

Also, Ajdary et al. [20] said that a high level of IFN- $\gamma$ production was observed to be associated with spontaneous lesion cure. Furthermore, chronic lesions and therapeutic failure had been associated with low level of IFN- $\gamma$ production.

Another studies confirm this fact, Castellano et al. [6] study that the antibody plasma levels and cytokine production in peripheral blood mononuclear cells (PBMC) culture supernatants in patients with active or healed lesions and revealed that higher IFN- $\gamma$ levels was observed in patients with active lesions and its persistence at elevated levels after lesion healing. Also Handjani et al. [10] demonstrated that the clinical healing of lesion of CL has been associated with Th-1 immune response 
characterized with high level of IFN- $\gamma$ production and decreased of Th-2 immune response and its related cytokine such IL-10.

On the other hand, the current results was disagreed with Ajdary et al. [21] showed that the level of IFN- $\gamma$ was similar between early and persisted CL patients but it was higher in comparison to control group. They concluded that non-healing patient of CL shows a mixed of Th1/Th2 responses whereas patients with acute lesion presents a Th1 response.

During the primary stage of infection the innate immune system of the host must quickly detect and respond to leishmania parasite infections, and this is performed by innate immune receptors. In the absence of recognition by innate immune receptors, the host will quickly become overwhelmed by parasite pathogens. On the other hand, if activation of innate immune receptors is too much, high levels of pro-inflammatory mediators such as TNF- $\alpha$ and IFN- $\gamma$ could be detrimental to the host [22]. The down-regulation of the immune response in CL patients is a transitory phenomenon for the reason that virtually all patients with more than 6 months of history of cutaneous lesion present strong IFN- $\gamma$ production. Also, this down-regulation of IFN- $\gamma$ production in CL can also account for parasite multiplication.

Also, the mean level of IFN- $\gamma$ cytokine observed significantly $(\mathrm{p}<0.01)$ high increase mean $(45.25$ $\pm 2.37 \mathrm{pg} / \mathrm{ml})$ in a single lesion patients in comparison to patients with multiple lesions, mean (38.79 \pm $1.10 \mathrm{pg} / \mathrm{ml})$, Table-3.

Galgamuwa et al. [23] found that the expression of IFN- $\gamma$ cytokine was higher in single lesions compared to people having multiple lesions of CL. Furthermore, these findings confirmed that levels of IFN- $\gamma$ was higher in serum patients with primary infection as compared with sera obtained from patients with secondary Leishmania infection [17]. These results were in line with the present result. The explanation of this increase may relat to the initial infection always characterized by high proinflamatory cytokines as IFN- $\gamma$, but when there is a secondary and tertiary etc. infection (ulcers) the immune response modulated towards Th- 2 and their cytokines such as (IL-10, IL-4, TGF- $\beta$ etc.) so that level of IFN- $\gamma$ tend to decrease and the parasite were increased in their intensity in multiple lesion. The results also showed that IFN- $\gamma$ level was significantly $(\mathrm{P}<0.01)$ higher in treated patients mean $(44.60 \pm 1.69 \mathrm{pg} / \mathrm{ml})$ in comparison to patients without treatment mean $(36.69 \pm 0.85 \mathrm{pg} / \mathrm{ml})$, Table-3. This results was consistent with preveous result that revealed a significant increase in IFN- $\gamma$ level during treatments in comparison to its level before treatment and this clarified that a successful treatment was activated T-cell proliferation in response to leishmania antigen [15].

Also, another finding confirms this fact, increased IFN- $\gamma$ production at the end of the treatment in human is due to the role of this cytokine in healing process and involvement of CD4+ T-cell in this process [24].

\section{Monokine induces by interferon gamma MIG}

The results of this study showed that patients with cutaneous leishmaniasis had higher significant $(\mathrm{P}<0.001)$ levels of total MIG mean $(257.08 \pm 8.54 \mathrm{pg} / \mathrm{ml})$ in comparison to the control group mean $(220.83 \pm 5.16 \mathrm{pg} / \mathrm{ml})$, Table- 4 .

Table 4-Mean level of MIG in CL patients in comparison to control group

\begin{tabular}{|c|c|c|c|}
\hline Group & Mean $\pm \mathrm{SE}(\mathrm{pg} / \mathrm{ml})$ & T-test & P-value \\
\hline Patients & $257.08 \pm 8.54$ & & \\
\hline Control & $220.83 \pm 5.16$ & $26.155 * *$ & 0.0071 \\
\hline \multicolumn{4}{|c|}{$* *(\mathbf{P}<0.001)$} \\
\hline
\end{tabular}

The current results was in agreements with previous results by Giudice et al, [25] who study peripheral blood mononuclear cell-derived macrophages which exposed to L.braziliensis in vitro and evaluated for susceptibility to the infection, the ability to kill Leishmania parasite and chemokine/cytokine production and their result found that macrophages from CL patients produced more chemokines and TNF- $\alpha$ than those from the healthy control group and the levels of MIG were significantly higher in CL.

Lesions of CL is characterized by an exacerbated cell-mediated immunity that forms a granuloma which contain many activated T-cells and produces a variety of cytokines [26]. The regulation of cellular migration from lymph organ to peripheral tissues plays a crucial role in the immune response. Chemokine and chemokine receptors are critical to the molecular mechanisms driving in this 
procedure. A combination of adhesion molecules and chemokine receptors mediate the recruitment of naive and memory $\mathrm{T}$ cells to peripheral tissue[27].

Cytokines are directly involved in chemokine manufacturing and can also precede the expression of chemokines.Th1-related chemokines such as induced protein-10 (IP-10) and monocyte chemoattractant protein(MCP) is induction by IL-12, and interferon (IFN)- $\gamma$ selectively induces IP-10 and MIG [28].

In Leishmania infection the role of chemokines has been exhaustively studied and these findings indicate that chemokines and chemokine receptors play an important role in detictive the outcome of the disease [29].

Additionally, MIG is secreted in high levels in auto-immune diseases such multiple sclerosis [30] and chronic inflammatory like human $\mathrm{T}$ cell lymphotropic virus infection. In both cases, MIG is associated with inflammation and the disease pathology [31].

The results as well showed that patients with early CL ( $<1$ month) mean $(279.55 \pm 13.28)$ had highest mean levels of MIG than other patients with different duration of infection, however late CL (>6 months) mean $(241.75 \pm 42.87 \mathrm{pg} / \mathrm{ml})$ showed higher level in comparison to (1-6 months) of infection but this result was non-significant, Table-5.

Moreover the results obtained that the level of MIG was lower in patients who had 1 lesion on their body mean $(256.17 \pm 14.76 \mathrm{pg} / \mathrm{ml})$ in comparison to patients who had multiple lesion mean $(257.63 \pm$ $10.54 \mathrm{pg} / \mathrm{ml})$, but this result also was non-significant, Table-5.

Table 5-Mean concentration of MIG in patients of CL according to duration of infection, number of lesion and treatment

\begin{tabular}{|c|c|c|c|}
\hline \multicolumn{2}{|c|}{ Group } & Mean \pm SE $(p g / m l)$ & LSD value \\
\hline \multirow{3}{*}{$\begin{array}{c}\text { Duration of } \\
\text { infection }\end{array}$} & Early infection & $279.55 \pm 13.28$ & \multirow{3}{*}{$60.575 \mathrm{NS}$} \\
\hline & Chronic infection & $230.22 \pm 7.84$ & \\
\hline & Late infection & $241.75 \pm 42.87$ & \\
\hline \multirow{2}{*}{$\begin{array}{c}\text { Number of } \\
\text { lesions }\end{array}$} & One lesion & $256.17 \pm 14.76$ & \multirow[b]{2}{*}{$35.462 \mathrm{NS}$} \\
\hline & Multiple lesions & $257.63 \pm 10.54$ & \\
\hline \multirow{2}{*}{ Treatment } & With treatment & $281.27 \pm 15.56$ & \multirow[b]{2}{*}{$32.943 * *$} \\
\hline & Without treatment & $238.12 \pm 8.04$ & \\
\hline
\end{tabular}

The present data was agree with Campanelli et al. [32] who detected that in the early stages of CL ( $<30$ days of infection) there was a higher expression of chemokine receptore (CXCR3) ckemokines than in late stages of disease ( $>60$ days of infection).

Moreover the results obtained that the mean level of MIG showed no significant difference $(\mathrm{P}>0.05)$ in patients who had one lesion on their body $(256.17 \pm 14.76 \mathrm{pg} / \mathrm{ml})$ in comparison to patients who had multiple lesion $(257.63 \pm 10.54 \mathrm{pg} / \mathrm{ml})$, Table- 5 .

The results also displayed that MIG mean level was significantly $(\mathrm{P}<0.01)$ decreased in patients without treatment in comparison to treated patients, Table-5.

Here in the present results the data showed an interestingly raised production of MIG during treatment in comparision to not treated one, this result was in agreement with previous result by Machado et al. [33] explained that MIG and IP-10 ckemokines were produced by the stimulation of leishmania antigen by clustered monocytic cells in the lesion.

\section{Conclusion}

From the current study the data investigated that there was an early effort to eliminate the parasite development which characterized by the high significant increase of IFN- $\gamma$ level that play a role in recruitments of T-cell to the site of infection for cell-mediated immunity, this thought illustrated by the increased level of MIG. But these efforts were down-regulated over time during the period (1-6 months) which may result from the immune manipulation of the parasite within the host as one of the strategies followed for immune evasion.

The down-regulation of the Th-1 cytokine in the present study seems transient because CL patients with late stage of infection presented a high significant level of IFN- $\gamma$, MIG. This increased in Th-1 cytokine may lead to clinical healing of CL lesion. 


\section{Recommendation}

Evaluation of the expression of the chemokines (CXCL10, CCL8, CCL9 and the chemokine receptors (CR3, CXCR3, CCR5) in the lesions of CL patients with different clinical forms by using immunohistochemistry. Studying the Immunohistochemical of skin biopsies to elucidate the cytokine release (IL-12, IL-4, and TNF- $\alpha$ ) capabilities of immune cells and for immune-phenotypic patterns (CD4, CD8, CD14, CD19 and CD56).

\section{ACKNOWLEGEMENT}

We would like to thank Baghdad University Baghdad /Iraq for its support to achieve this work and for all the staff of Al-Karama Hospital/ Dermatology Departments for their helping in collecting the sample.

\section{References}

1. Marques-da-Silva, C., Chaves, M. M., Thorstenberg, M. L., Figliuolo, V. R., Vieira, F. S., Chaves, S. P. and Coutinho-Silva, R. 2018. Intralesional uridine-5'-triphosphate (UTP) treatment induced resistance to Leishmania amazonensis infection by boosting Th1 immune responses and reactive oxygen species production. Purinergic Signalling, 14(2): 201-211.

2. Sundar, S. and Singh, O. P. 2018. Molecular Diagnosis of Visceral Leishmaniasis. Molecular Diagnosis and Therapy, 22: 443-457.

3. Kumar, R., Bumb, R. A. and Salotra, P. 2010. Evaluation of localized and systemic immune responses in cutaneous leishmaniasis caused by Leishmania tropica: Interleukin-8, monocyte chemotactic protein-1 and nitric oxide are major regulatory factors. Immunology, 130(2): 193-201.

4. Vries, H. J. C., Reedijk, S. H. and Schallig, H. D. F. H. 2015. Cutaneous leishmaniasis: recent developments in diagnosis and management. American Journal of Clinical Dermatology, 16(2): 99-109.

5. Maciej-Hulme, M. L., Skidmore, M. A. and Price, H. P. 2018. The role of heparan sulfate in host macrophage infection by Leishmania species. Biochemical Society Transactions, 46(4): 789-796.

6. Castellano, L. R., Filho, D. C., Argiro, L., Dessein, H., Prata, A., Dessein, A. and Rodrigues, V. 2009. Th1/Th2 immune responses are associated with active cutaneous leishmaniasis and clinical cure is associated with strong interferon- $\gamma$ production. Human Immunology, 70(6): 383-390.

7. Costa, R. S., Carvalho, L. P., Campos, T. M., Magalhães, A. S., Passos, S. T., Schriefer, A. and Carvalho, E. M. 2018. Early cutaneous leishmaniasis patients infected with leishmania braziliensis express increased inflammatory responses after antimony therapy. Journal of Infectious Diseases, 217(5): 840-850.

8. Meymandi, S., Dabiri, S., Shamsi-Meymandi, M., Nikpour, H. and Kharazmi, A. 2009. Immunophenotypic pattern and cytokine profiles of dry type cutaneous leishmaniasis. Archives of Iranian Medicine, 12(4): 371-376.

9. Hejazi, S. H., Hoseini, S. G., Javanmard, S. H., Zarkesh, S. H. and Khamesipour, A. 2012. Interleukin-10 and transforming growth factor- $\beta$ in early and late lesions of patients with Leishmania major induced cutaneous leishmaniasis. Iranian Journal of Parasitology, 7(2): 53.

10. Handjani, F., Yousef, S. R., Saki, N. and Hamidizadeh, N. 2017. Interleukin-10 and Interferon- $\gamma$ Levels in Patients with Cutaneous Leishmaniasis Treated with Cryotherapy. Iranian Journal of Medical Sciences, 42(5): 488-492.

11. Whiting, D., Hsieh, G., Yun, J. J., Banerji, A., Yao, W., Fishbein, M. C. and Ardehali, A. 2004. Chemokine monokine induced by IFN- $\gamma / \mathrm{CXC}$ chemokine ligand 9 stimulates $\mathrm{T}$ lymphocyte proliferation and effector cytokine production. The Journal of Immunology, 172(12): 7417-7424.

12. Shimada, Y., Takehara, K. and Sato, S. 2004. Both Th2 and Th1 chemokines (TARC/CCL17, MDC/CCL22, and Mig/CXCL9) are elevated in sera from patients with atopic dermatitis. Journal of dermatological science, 34(3): 201-208.

13. SAS. 2012. Statistical Analysis System, User's Guide. Statistical. Version $9.1^{\text {th }}$ ed. SAS. Inst. Inc. Cary. N.C. USA.

14. Al-Qadhi, B. N., Musa, I. S. and Hummadi, Y. M. K. A.-M. 2015. Comparative immune study on cutaneous leishmaniasis patients with single and multiple sores. Journal of Parasitic Diseases, 39(3): 361-370.

15. Al-Aubaidi, I. K. 2011. Serum cytokine production in patients with cutaneous leishmaniasis before and after treatment. Iraqi Journal of Medical Sciences, 9(1): 55-60.

16. Barral, A., Teixeira, M., Reis, P., Vinhas, V., Costa, J., Lessa, H. and Barral-Netto, M. 1995. 
Transforming growth factor-beta in human cutaneous leishmaniasis. The American Journal of Pathology, 147(4): 947-954.

17. Espir, T. T., Figueira, L. de P., Naiff, M. de F., da Costa, A. G., Ramalho-Ortigão, M., Malheiro, A. and Franco, A. M. R. 2014. The role of inflammatory, anti-inflammatory, and regulatory cytokines in patients infected with cutaneous leishmaniasis in Amazonas state, Brazil. Journal of Immunology Research, 2014: 481750.

18. Taheri, A. R., Mashayekhi Goyonlo, V., Nahidi, Y., Moheghi, N. and Tavakkol Afshari, J. 2014. Plasma levels of interlukin-4 and Interferon- $\gamma$ in patients with chronic or healed cutaneous leishmaniasis. Iranian Journal of Basic Medical Sciences, 17(3): 216-219.

19. Bacellar, O., Lessa, H., Schriefer, A., Machado, P., Ribeiro de Jesus, A., Dutra, W. O. and Carvalho, E. M. 2002. Up-regulation of Th1-type responses in mucosal leishmaniasis patients. Infection and Immunity, 70(12): 6734-6740.

20. Ajdary, S, Alimohammadian, M. H., Eslami, M. B., Kemp, K. and Kharazmi, A. 2000. Comparison of the immune profile of nonhealing cutaneous Leishmaniasis patients with those with active lesions and those who have recovered from infection. Infection and Immunity, 68(4): 17601764.

21. Ajdary, Soheila, Riazi-Rad, F., Alimohammadian, M.-H. and Pakzad, S.-R. 2009. Immune response to Leishmania antigen in anthroponotic cutaneous leishmaniasis. Journal of Infection, 59(2): 139-143.

22. Vieira, É. L. M., Keesen, T. S. L., Machado, P. R., Guimarães, L. H., Carvalho, E. M., Dutra, W. O. and Gollob, K. J. 2013. Immunoregulatory profile of monocytes from cutaneous leishmaniasis patients and association with lesion size. Parasite Immunology, 35(2): 65-72.

23. Galgamuwa, L. S., Sumanasena, B., Iddawela, D., Wickramasinghe, S. and Yatawara, L. 2019. Assessment of intralesional cytokine profile of cutaneous leishmaniasis caused by Leishmania donovani in Sri Lanka. BMC Microbiology, 19(1): 14.

24. Cruz, A. M., Conceição-Silva, F., Bertho, A. L. and Coutinho, S. G. 1994. Leishmania-reactive CD4+ and CD8+ T cells associated with cure of human cutaneous leishmaniasis. Infection and Immunity, 62(6): 2614-2618.

25. Giudice, A., Vendrame, C., Bezerra, C., Carvalho, L. P., Delavechia, T., Carvalho, E. M. and Bacellar, O. 2012. Macrophages participate in host protection and the disease pathology associated with Leishmania braziliensis infection. BMC Infectious Diseases, 12(1): 75.

26. Diaz, N L, Zerpa, O., Ponce, L. V, Convit, J., Rondon, A. J. and Tapia, F. J. 2002. Intermediate or chronic cutaneous leishmaniasis: leukocyte immunophenotypes and cytokine characterisation of the lesion. Experimental Dermatology, 11(1): 34-41.

27. Laudanna, C., Kim, J. Y., Constantin, G. and Butcher, E. 2002. Rapid leukocyte integrin activation by chemokines. Immunological Reviews, 186: 37-46.

28. Diaz, Nilka Luisa, Zerpa, O., Tapia, F. J., Diaz, N. L., Zerpa, O. and Tapia, F. J. 2013. Chemokines and chemokine receptors expression in the lesions of patients with American cutaneous leishmaniasis. Memórias Do Instituto Oswaldo Cruz, 108(4): 446-452.

29. Teixeira, M. J., Teixeira, C. R., Andrade, B. B., Barral-Netto, M. and Barral, A. 2006. Chemokines in host-parasiteinteractions in leishmaniasis. Trends in Parasitology, 22(1): 32-40.

30. Trebst, C. and Ransohoff, R. M. 2001. Investigating chemokines and chemokine receptors in patients with multiple sclerosis: opportunities and challenges. Archives of Neurology, 58(12): 1975-1980.

31. Guerreiro, J. B., Santos, S. B., Morgan, D. J., Porto, A. F., Muniz, A. L., Ho, J. L. and Carvalho, E. M. 2006. Levels of serum chemokines discriminate clinical myelopathy associated with human T lymphotropic virus type 1 (HTLV-1)/tropical spastic paraparesis (HAM/TSP) disease from HTLV-1 carrier state. Clinical and Experimental Immunology, 145(2): 296-301.

32. Campanelli, A. P., Brodskyn, C. I., Boaventura, V., Silva, C., Roselino, A. M., Costa, J. and Barral, A. 2010. Chemokines and chemokine receptors coordinate the inflammatory immune response in human cutaneous leishmaniasis. Human Immunology, 71(12): 1220-1227.

33. Machado, P. R. L., Dourado, M., Brito, G., Queiroz, A., Carvalho, L. P., Celestino, D. and Carvalho, E. M. 2014. Clinical and Immunological Outcome in Cutaneous Leishmaniasis Patients Treated with Pentoxifylline. The American Journal of Tropical Medicine and Hygiene, 90(4): $617-620$. 